\title{
Development of an Acehnese Value-Based Education Implementation Model at SMK Negeri 7
}

\author{
Taufiq $^{1}$, Siraj $^{1}$, Sayni Nasrah ${ }^{2 *}$ \\ ${ }^{1}$ Department of Mechanical Engineering Vocational Education, Universitas Malikussaleh, Aceh, Indonesia \\ ${ }^{2}$ Department of Indonesian Language Education, Universitas Malikussaleh, Aceh, Indonesia \\ *Corresponding author E-mail: sayni.nasrah@unimal.ac.id
}

\begin{abstract}
Manuscript received 16 Nov 2021; revised 20 Nov 2021; accepted 1 Jan 2022. Date of publication 10 Jan 2022

The values of Islamic character should be the spirit that colors all aspects of education, both in classroom-based learning, the climate of school life, as well as in the context of interaction with community life in general, integrated into learning starting from planning, implementing, and evaluating according to the characteristics Basic Competence. Learning in vocational schools needs to be designed according to the demands of the curriculum in an effort to instill Acehnese values through production-based training/production-based education and training and Islamic edutechnopreneur learning practices. The objectives of this research are to: 1) Develop a model of education implementation based on Acehnese values through the Islamic Edutechnopreneur model; 2) Testing the quality of the education delivery model; and 3) Analyzing teacher and student responses to the Acehnese values-based education model through the Islamic Edutechnopreneur model that has been developed at SMK Negeri 7 Lhokseumawe. This study uses the Research and Development method. The importance of this research is because vocational and school teachers really need a model of Islamic edutechnopreneur-based education and its implementation in school life. The results showed that the success of the Edutechnopreneur production unit at SMK Negeri 7 Lhokseumawe really depends on the management applied in the school. Therefore, it is important to strengthen SMK management so that Islamic Edutechnopreneur production units can be developed in an effort to strengthen the competitiveness of graduates. Teachers are an important resource, involve teachers in various trainings that enable them to develop in mastery of competencies and achieve increased insight and entrepreneurial skills.
\end{abstract}

Keywords: Education Model, Aceh, Islamic Edutechnopreneur.

\section{Introduction}

Aceh is one of the Special Regions with community characteristics that are identical to Islam with a strong socio-cultural and religious identity. These characteristics make the people of Aceh transformed into advantages among the plurality of various ethnic groups that exist in Indonesia. Through this Islamic identity, the people of Aceh have local cultural values that cannot be separated from Islamic values. The acculturation of these values makes local wisdom that has synergized between Islamic teachings and customs [1] [2] [3].

Presidential Instruction (Inpres) Number 9 of 2016 concerning Revitalization of Vocational High Schools (SMK) in the Context of Improving the Quality and Competitiveness of Indonesian Human Resources, has encouraged many parties to make various efforts to realize the spirit contained in the Inpres, namely improving the quality of the process and results of education in SMK in order to actually produce quality graduates as expected. The Aceh government, in this case the Aceh Education Office as the party most responsible for providing education at vocational schools in Aceh, responded to the Presidential Instruction, among others, by immediately issuing Aceh Governor Regulation Number 66 of 2019 concerning Technology-Based Education Curriculum and Islamic Entrepreneurship at Vocational High Schools in Aceh [4] [5] [6].

Based on the data from field observations, it was found that the teachers of SMK Negeri 7 Lhokseumawe still have difficulty in describing learning practices through the integration of Acehnese values in developing an entrepreneurial spirit, fostering work attitudes and discipline, developing responsibility and maturity in strengthening human resources, problem-solving skills, self-confidence, and increase students' desire to make a business [7] [8].

Facing the problems mentioned above, an effort is needed to rebuild the integration of Acehnese local wisdom values that have high fighting power/spirit in learning/business. The next effort is the need for a model for developing the values of local wisdom in learning activities. This is in line with the Aceh Government's policy in Aceh Qanun Number 11 of 2014 concerning the Implementation of Education which contains Islamic, national and Acehnese colors. Then the Aceh Governor Regulation Number 66 of 2019 was strengthened regarding the Technology-Based Education Curriculum and Islamic Entrepreneurship at Vocational High Schools in Aceh. The importance of this research is because vocational and school teachers really need a model of Islamic edutechnopreneur-based education and its implementation in school life. The novelty in this research is to improve/revise the model of providing education based on Acehnese values 
through the Islamic Edutechnopreneur model. Based on the background of the problems that have been stated, the formulations of the problems in this study are [9] [10] [11]:

1. How is the model of providing education based on Acehnese values through the Islamic Edutechnopreneur model?

2. What is the quality of the Acehnese values-based education model through the Islamic Edutechnopreneur model?

3. How do teachers and students respond to the Acehnese values-based education model through the Islamic Edutechnopreneur model that has been developed at SMK Negeri 7 Lhokseumawe?

\section{Literature Review}

Teachers as professional workers must uphold professionalism in carrying out their duties. Professionalism refers to the attitude of members of the profession towards their profession and the degree of knowledge and expertise they have in carrying out their work. In the concept of Islamic education, the position of the teacher is so respectable, the teacher is positioned as a pious, wara, pious and uswah person so that teachers are required to also do good deeds as the actualization of their knowledge. The formation of teacher professionalism can be done through efforts to build professional teacher competencies based on Islamic values, creating a conducive learning environment characterized by Islamic values, creating an effective learning atmosphere with Islamic characteristics, and supporting the achievement of national education goals by developing various professional competencies [12].

The implementation of the main task of the teacher cannot be separated from the ability of a teacher in the mastery and application of his competence. Mastery and application of competence will determine the achievement of the quality of the learning process, guidance of students, and the implementation of relevant additional tasks in accordance with the function of the school. For this reason, it is necessary to develop a teacher performance appraisal system [13].

The teacher performance appraisal system is a teacher-based performance management system designed to evaluate individual teacher performance levels in order to achieve maximum school performance which has an impact on increasing student achievement. A positive psychological state and self-fulfillment to contribute to organizational success characterized by strength, dedication, and absorption are the dominant factors influencing teacher performance. Unity attitude and emotions that include enthusiasm, dedication, absorption, and passion that can stimulate teacher involvement in lesson planning, implementation, and evaluation [14].

The implementation of the main task of the teacher cannot be separated from the ability of a teacher in the mastery and application of his competence. Mastery and application of competence will determine the achievement of the quality of the learning process, guidance of students, and the implementation of relevant additional tasks in accordance with the function of the school. For this reason, it is necessary to develop a teacher performance appraisal system. The teacher performance appraisal system is a teacher-based performance management system designed to evaluate individual teacher performance levels in order to achieve maximum school performance which has an impact on increasing student achievement. Suggests that a positive psychological state and self-fulfillment to contribute to organizational success characterized by strength, dedication, and absorption are the dominant factors influencing teacher performance. Unity attitude and emotions that include enthusiasm, dedication, absorption, and passion that can stimulate teacher involvement in lesson planning, implementation, and evaluation [15].

The professional characteristics of SMK teachers can be seen from a minimum of 8 (eight) professional requirements which are a combination of requirements proposed by experts and the mandate of the Law on Teachers. If the vocational school teacher can meet these requirements, then he is called a professional teacher. It is proposed 2 (two) ways to prepare professional SMK teachers, namely through initial professional development and further professional development. Initial professional development is carried out by: (1) limited acceptance of prospective teachers by tracking interests, talents and abilities, (2) intensive, disciplined, directed, regular education and training in LPTKs, (3) provision of residential dormitories, (4) financing of all activities and scholarships, (5) apprenticeship in industry and vocational schools, and (6) appropriate work assignments. Further professional development is carried out by: (1) practicing industrial experience, (2) technical competency testing, (3) on-the-job training, (4) being active in professional associations, (5) continuing academic education, (6) providing professional allowances education, and (7) financing all professional development activities [16].

These Islamic values should be the spirit that characterizes all aspects of the implementation of education, both in classroom-based learning, the climate of school life, as well as in the context of interaction with community life in general. In accordance with this, of course, Vocational High Schools (SMK) can apply the Islamic Edutechnopreneur education model. By preparing students psychologically and physically to participate in the learning process and strengthening the character values of Dinul Islam, including tolerance, empathy, friendship, religion, love for the environment, local culture, cleanliness and discipline. In order to achieve this capability, learning in vocational schools needs to be designed in accordance with the demands of the curriculum in an effort to inculcate Acehnese values through production-based training/production-based education and training and Islamic edutechnopreneur learning practices [16] [17].

Based on the research roadmap, this study (2021) tries to develop a model for providing Acehnese values-based education at SMK Negeri 7 Lhokseumawe. The new finding in this basic research is to improve/revise the Acehnese values-based education delivery model through the Islamic Edutechnopreneur model. The direction of the next research development model of this education implementation can be applied in all SMK in the field of mechanical engineering in Lhokseumawe City [18] [19] [20].

\section{Methods}

This research uses research and development methods (Research and Development) Borg and Gall. The Borg and Gall development research model was carried out through 10 stages, namely: 1) research and data collection; 2) planning; 3) product draft development; 4) initial field trials; 5) revise the results of the trial; 6) field trials; 7) refinement of products from field trials; 8) field implementation test; 9) final product refinement; and 10) dissemination and implementation.

This research model was developed through four stages, namely: 1) preliminary study; 2) planning; 3) development of education delivery model; and 4) model validation by evaluation. The research design starts from the analysis, design, development, implementation, and evaluation phases. The model of providing education based on Acehnese values through the Islamic Edutechnopreneur model can absorb knowledge, skills, attitudes, and interact with principals, teachers, staff and students in acquiring and deepening knowledge. The results obtained can be known through reflection activities. For this reason, steps are needed in building a model of providing education based on Acehnese values through an effective and efficient Islamic Edutechnopreneur model. These steps relate to teacher needs, formulation of objectives, selection of methods, and evaluation. The evaluation was conducted to find out whether the Acehnese values-based education model through the Islamic Edutechnopreneur model is appropriate or not, and to compare the costs and benefits of various program activities that have been implemented in schools. 
The model of providing education based on Acehnese values through the Islamic Edutechnopreneur model was developed through three stages, namely: 1) a preliminary study, which identified various problems related to the implementation of the education system in SMK; 2) planning, namely formulating goals, selecting effective methods and exercises; 3 ) developing a model for providing education based on Acehnese values through the Islamic Edutechnopreneur model; and 4) validation of the model of providing education based on Acehnese values through the Islamic Edutechnopreneur model by measuring the process and results of activities. The evaluation activity includes measuring the level of efficiency and effectiveness of the implementation of Acehnese values-based education through the Islamic Edutechnopreneur model. Furthermore, the Step Wise Model regression test was carried out to find the determinants of the success of developing a model of Aceh values-based education through the Islamic Edutechnopreneur model at SMK Negeri 7 Lhokseumawe.

\section{Results and Discussion}

The production unit of Edutechnopreneur Islami is a model for the educational curriculum of the Aceh Vocational High School (SMK) based on Islamic technology and entrepreneurship. The added value of the model is generating income for school residents and increasing the use factor of school resources, in the form of machine tools as well as human resources and natural resources and managed in an Islamic way (according to shari'ah). The Islamic Edutechnopreneur production unit is a teaching unit with a special block system for productive subjects at SMK Negeri 7 Lhokseumawe and is also a production and service management institution that generates income for schools and school residents. This teaching approach is expected to have an impact or benefit for the institution or other parties involved in it. This production unit standard builds industry at school or outside of school and can work together with other industries continuously, this will automatically become a real training tool (on the job training and work based learning) for all students, teaching staff/instructors and alumni in the fields of technology and entrepreneurship, so that the industrial climate can be absorbed in real terms and this will be able to increase each other's professionalism. Furthermore, the profits of the Islamic Edutechnopreneur production unit can be used to support the operational costs of education and institutional development. Vocational High School (SMK) as an educational institution that carries out a production-based learning process is very possible to produce products that are worthy of being sold and able to compete in the market. Therefore, SMK Negeri 7 Lhokseumawe should develop Edutechnopreneurs that are relevant to the skill programs developed in schools in a programmed and structured manner.

The reality in the field is that SMK Negeri 7 Lhokseumawe is able to produce quality products, but for one reason or another it has not been able to market it so an institution is needed that can facilitate the marketing of these products. This can be overcome, among others, by enabling one of the schools that has the ability in the field of marketing to become an outlet.

The implementation of the Islamic Edutechnopreneur production unit at SMK Negeri 7 Lhokseumawe aims to:

a. Production/service-based training vehicle for students;

b. A vehicle for growing and developing the entrepreneurial spirit of teachers and students in SMK;

c. Means of direct productive practice for students;

d. Assist in funding for maintenance, additional facilities and other educational operational costs;

e. Increase the spirit of togetherness, because it can be a vehicle for increasing the productive activities of teachers and students as well as providing 'income' and increasing the welfare of school residents;

f. Develop an independent and confident attitude in the implementation of students' practical activities;

g. Train to dare to take risks with careful calculations;

h. Support the implementation and achievement of a complete Dual System Education (PSG) and Education Unit Level Curriculum, providing opportunities for students and teachers to undertake market-oriented practical work, enhancing creativity and innovation among students, teachers and school management;

i. Foster a productive professional attitude in students and teachers;

j. Train students not to depend on others, but to be independent, especially in getting job opportunities;

k. The Dual System Education (PSG) forum for students who do not get a place for industrial work practices in the business and industrial world;

1. Establish better relations with the business and industrial world as well as other communities for the opening of facilities to the public and their products;

m. Increase the intensity and frequency of students' intra, co, and extra-curricular activities; and

n. Build the school's ability to establish synergistic cooperation with external parties and the environment as well as the wider community.

The results of the research at SMK Negeri 7 Lhokseumawe found that the benefits of the Islamic Edutechnopreneur production unit in the context of technical and vocational education, learning resources must be oriented and relevant to the world of work, according to the National Technical and Vocational Education and Training Program (1996:3) vocational education is identical with education work that is directly related to the preparation of a person to enter the world of work. Roberts (1977:23-25) says that historically vocational education is the development of job training. In job training, students can learn while working. This means that while working is a characteristic of learning in vocational schools. Thus the concept of Work-based Learning becomes very relevant to be applied in SMK. Islamic Edutechnopreneur production unit. Apart from being a source of learning, it is hoped that it will also be a source of funding, so that the sustainability of a business will continue to be maintained. Thus schools, students and teachers who are involved in the business process will get income generating.

The success of the Edutechnopreneur production unit at SMK Negeri 7 Lhokseumawe really depends on the management applied at the school. Therefore, it is important to strengthen SMK management so that Islamic Edutechnopreneur production units can be developed in an effort to strengthen the competitiveness of graduates. Some steps that can be taken as a challenge include:

1. Strengthen the entrepreneurial spirit, because the entrepreneur is also a leader who is able to influence and convince the group in developing their ideas by working together to trust each other. A firm commitment in seeking and creating these opportunities can be fostered by simplifying the bureaucracy and clearly delegating authority to business partners and subordinates in running the business and in making decisions;

2. Awareness of the Edutechnopreneur production unit in the Vocational High School is required, the existence of the Edutechnopreneur production unit in the Vocational School should be able to overcome problems related to the production of student practice results. Edutechnopreneur can be a place that accommodates student products; be a quality control over student products; become a marketing team; Become a sales agent who can make a direct contribution to students getting sales results. In an effort to develop this awareness, a transparent management climate is needed so that all school residents can see firsthand the various benefits obtained ; 
3. Orderly administration, administrative aspects often receive less attention in small businesses in Indonesia. Edutechnopreneurs should keep records of every transaction that can be learned by school members. Edutechnopreneur operating data can be a means to examine various matters related to business development, for example the types of requests that are most often submitted by customers, types of products that tend to be needed at certain times, types of products that are in demand by certain circles, where do you live customers, when the profit is greatest, when the product reaches its peak or vice versa when demand is at its lowest. In practical learning, students need to be given the opportunity to work quickly and accurately. This means that all tasks are completed correctly in the shortest possible time with the right procedures. However, when students have demonstrated mastery of competencies, they need to be challenged to be creative and innovative. This challenge will stimulate competition among students, especially if given a consistent reward system;

4. Create a 'Market' climate in schools, giving students and teachers the opportunity to do 'buying and selling' in schools. For example, between students and students with teachers or vice versa between teachers and students. They can buy and sell each other to meet each other's needs. Next, encourage students to buy and sell in their family environment and continue with buying and selling with the surrounding community. In this way it will form a spider network that leads to the school;

5. Conditioning the school environment, start by instilling the values that exist in the industry to occur and take place in schools. Some values that can be started to be conditioned are cleanliness, order, discipline, and friendliness to each guest. This condition must be created and become a school culture, because with the creation of these conditions the school community, especially students, will experience the real business environment/world. Because in the business world always strive for an atmosphere that is orderly, disciplined, friendly to customers and always maintains cleanliness to provide comfort to customers and relations;

6. Teachers are an important resource, involve teachers in various trainings that enable them to develop in mastery of competencies and achieve increased insight and entrepreneurial skills. Teachers as an important asset of SMK will be agents of change in the student's learning climate. If necessary, teachers need to find opportunities to conduct on the job training in small and medium business units. Training related to product and service innovation related to their expertise program and field will be an added value for the teacher's personal and school interests;

7. Opening various references, learning with multiple references and varied methods will be an attraction for students to pursue it. Students need to be brought to see the possibility of seeking information and ideas as well as learning resources from various types of references. Using survey methods to the field/market, surfing the internet, studying advertisements, sharing economic and business news, reading success stories, will be a learning experience that gives a lot of knowledg

In developing the organization, several things must be considered in making the organizational structure of Edutechnopreneurs at SMK Negeri 7 Lhokseumawe, among others: a) the organization and management of Edutechnopreneurs are arranged in a flat manner, which emphasizes more on team work. As team members, employees are involved and empowered to contribute to management in realizing customer satisfaction and clear delegation of duties and authority to each work unit and implementer; b) developing the principle of 'decentralization' and authority in the division of tasks and powers; c) roles and responsibilities of personnel and managers are clear, to be able to grow the business without being constrained by rigid bureaucratic lines; d) school leadership style is flexible, flexible and democratic, to be able to establish communication and filter information quickly for the benefit of Edutechnopreneurs; e) staffing, carried out in activities related to HR management in the development of edutechnopreneurs which include: recruitment, selection, orientation placement, reward, training unit, promotion and performance appraisal; f) control is carried out to make arrangements or directions within the organization so that goals are achieved. 1) Physical control, for example: raw materials, product quality, production equipment, machine capacity, etc.; g) personnel control, including: Placement of new workers, employee training, remuneration and work performance; h) control information, including: marketing and sales information, environmental analysis information, production schedule; and financial control.

\section{Conclusion}

The Success Of The Edutechnopreneur Production Unit At Smk Negeri 7 Lhokseumawe Really Depends On The Management Applied At The School. Therefore, It Is Important To Strengthen Smk Management So That Islamic Edutechnopreneur Production Units Can Be Developed In An Effort To Strengthen The Competitiveness Of Graduates. Teachers Are An Important Resource, Involve Teachers In Various Trainings That Enable Them To Develop In Mastery Of Competencies And Achieve Increased Insight And Entrepreneurial Skills.

\section{Acknowledgement}

Gratefully acknowledges financial support from The Institute for Research and Community Service (LPPM) Universitas Malikussaleh, Aceh, Indonesia.

\section{References}

[1] K. Bustamam-ahmad, "Educational practice : lessons to be learned from madrasah and religious," Indones. J. Islam Muslim Soc., 2015.

[2] F. Barri, "MANAJEMEN WAKTU SANTRI DI DAYAH TAHFIDZ ULUMUL QUR'AN PAGAR AIR BANDA ACEH,” $J . I l m$. Didakt., 2017, doi: 10.22373/jid.v17i1.1593.

[3] S. H. Hamzah, K. Kunci, : Perkembangan, P. D. Orla, and R. Orba, "PERKEMBANGAN PESANTREN DI INDONESIA (Era Orde Lama, Orde Baru, Reformasi)," Syamil, 2014.

[4] S. Irawan, T. W. Panjaitan, and L. Yenny Bendatu, "/ Penyusunan Hazard Identification Risk Assessment and Risk Control (HIRARC) di PT," J. Titra, 2015.

[5] F. Falahuddin, F. Fuadi, and M. R. Ramadhan, "Faktor-Faktor yang mempengaruhi Minat Wakaf Masyarakat di Kota Lhokseumawe," J. EMT KITA, vol. 3, no. 2, 2019, doi: 10.35870/emt.v3i2.111.

[6] M. I. Ansari, "Partai Politik Lokal Dalam Tata Hukum Indonesia," Tanjung Pura Law Juornal, vol. 1, no. $2,2017$.

[7] D. prayitno, edy, "Pemanfaatan Teknologi Informasi Untuk Meningkatkan Kualitas Pembelajaran," TECHSI - J. Tek. Inform.

[8] M. Muthmainnah, F. Fajriana, and D. Siska, "PEMANFAATAN TEKNOLOGI INFORMASI UNTUK MENINGKATKAN KUALITAS PEMBELAJARAN,” TECHSI - J. Tek. Inform., 2017, doi: 10.29103/TECHSI.V9I2.214. 
[9] J. R. Coyanda, "Model Technopreneur IT Mahasiswa Pada Masa Pandemic Covid 19 dengan Metode Business Model Canvas," J. Ilm. Inform. Glob., vol. 11, no. 1, 2020, doi: 10.36982/jig.v11i1.1069.

[10] M. Hasdar, M. Fera, and M. Syaifulloh, "Pemberdayaan Kelompok Bisnis Mahasiswa Berbasis IPTEK Melalui Program Agrofood Technopreneur," J. SOLMA, vol. 8, no. 1, 2019, doi: 10.29405/solma.v8i1.3206.

[11] D. Abdullah, C. I. Erliana, and M. Fikry, "Data Envelopment Analysis with Lower Bound on Input to Measure Efficiency Performance of Department in Universitas Malikussaleh," Int. J. Artif. Intell. Res., vol. 4, no. 1, 2020, doi: 10.29099/ijair.v4i1.164.

[12] A. B. H. Tamuri, M. Khairul, and A. Ajuhary, "Amalan Pengajaran Guru Pendidikan Islam Berkesan Berteraskan Konsep Mu 'allim," J. Islam. Arab. Educ., 2010.

[13] P. Barbaro et al., "Safety Data Sheet," J. Am. Chem. Soc., 2009, doi: 10.1021/jm701266y.

[14] B. Dwi Cahyono and D. Sulastri, "Development Of Electrical Installation Learning Me-dia With Delphi Language,” Int. J. Eng. Sci. Inf. Technol., vol. 1, no. 3, 2021, doi: 10.52088/ijesty.v1i3.81.

[15] D. Riyan Rizaldi, A. Doyan, Z. Fatimah, M. Zaenudin, and M. Zaini, "Strategies to Improve Teacher Ability in Using The Madrasah E-Learning Application During the COVID-19 Pandemic," Int. J. Eng. Sci. Inf. Technol., vol. 1, no. 2, 2021, doi: 10.52088/ijesty.v1i2.47.

[16] A. Ahyanuardi, H. Hambali, and K. Krismadinata, "Pengaruh Kompetensi Pedagogik Dan Profesional Guru Sekolah Menengah Kejuruan Pasca Sertfikasi Terhadap Komitmen Guru Melaksanakan Proses Pembelajaran," INVOTEK J. Inov. Vokasional dan Teknol., vol. 18, no. 1, 2018, doi: 10.24036/invotek.v18i1.169.

[17] M. Arief, M. Churiyah, A. Basuki, B. Adi, and A. Gunawan, "Peningkatan Kompetensi Guru Smk Kabupaten," J. Graha Pengabdi., vol. 2, no. 43, 2020.

[18] I. Indrayani and K. Khairunnisa, "ANALISIS PENGUKURAN KINERJA DENGAN MENGGUNAKAN KONSEP VALUE FOR MONEY PADA PEMERINTAH KOTA LHOKSEUMAWE: (STUDI KASUS PADA DPKAD KOTA LHOKSEUMAWE PERIODE 2014-2016)," J. Akunt. dan Keuang., vol. 6, no. 1, 2019, doi: 10.29103/jak.v6i1.1820.

[19] G. Zabandan, "Several integral inequalities and their applications on means," Int. J. Nonlinear Anal. Appl., vol. 12, no. 2, 2021, doi: 10.22075/ijnaa.2021.23169.2486.

[20] E. Sorouri, M. Eshaghi Gordji, and R. Memarbashi, "An analysis of a fishing model with nonlinear harvesting function," Int. J. Nonlinear Anal. Appl., vol. 11, no. 1, 2020, doi: 10.22075/IJNAA.2020.4217. 